\section{REFERENCES AND NOTES}

1. Bolin, T. D., McKern, A., and Davis, A. E.: The effect of diet on lactase activity in the rat. Gastroenterology, 60: 432 (1971).

2. Broitman, S. A., Thalenfeld, B. E., and Zamcheck, N.: Alterations in gut lactase activity in young and adult rats fed lactose. Fed. Proc., 27: 573 (1968).

3. Cain, G. D., Moore, P., Jr., Patterson, M., and McElveen, M. A.: The stimulation of lactase by feeding lactose. Scand. J. Gastroenterol., 4: 545 (1969).

4. Dahlqvist, A.: Assay of intestinal disaccharidases. Anal. Biochem., 22: 99 (1968).

5. Doell, R. G., and Kretchmer, N.: Studies of small intestine during development. 1. Distribution and activity of $\beta$-galactosidase. Biochim. Biophys. Acta, 62:353 (1962).

6. Farrell, P. M., and Zachman, R. D.: Induction of choline phosphotransferase and lecithin synthesis in the fetal lung by cortiocosteroids. Science, 179: 297 (1973).

7. Ferguson, A., Gerskowitch, V. P., and Russell, R. I.: Pre- and postweaning disaccharidase patterns in isografts of fetal mouse intestine. Gastroenterology, 64: 292 (1973).

8. Fischer, J. E.: Effects of feeding a diet containing lactose upon $\beta$-d-galactosidase activity and organ development in the rat digestive tract. Amer. J. Physiol. 188: 49 (1957).

9. Girardet, P., Richterich, R., and Antener, I.: Adaptation de la lactase intestinale à l'administration de lactose chez le rat adulte. Helv. Physiol. Pharmacol. Acta, 22: 7 (1964).

10. Knudsen, K., Bradley, E. M., Lecocq, F. R., Bellamy, H. M., and Welsh, J. D.: Effect of fasting and refeeding on the histology and disaccharidase activity of the human intestine. Gastroenterology, 55: 46 (1968).

11. Koldovsky, O.: Development of the Functions of the Small Intestine in Mammals and Man (Karger, White Plains, N. Y., 1969).

12. Kotas, R. V., and Avery, M. E.: Accelerated appearance of pulmonary surfactant in the fetal rabbit. J. Appl. Physiol., 30: 358 (1971).
13. Lev, R., and Orlic, D.: Protein absorption by the intestine of the fetal rat in utero. Science, 177: 522 (1972).

4. Liggins, G. C., and Howie, R. N.: A controlled trial of antepartum glucocorticoid treatment for prevention of the respiratory distress syndrome in premature infants. Pediatrics, 50: 515 (1972).

15. Lowry, O. H., Rosebrough, N. J., Farr, A. L., and Randall, R. J.: Protein measurement with the Folin phenol reagent. J. Biol. Chem., 193: 265 (1951).

16. Moog, F., and Richardson, D.: The functional differentiation of the small intestine. IV. The influence of adrenocortical hormones on differentiation and phosphatase synthesis in the duodenum of the chick embryo. J. Exp. Zool., 130: 29 (1955)

17. Orlic, D., and Lev, R.: Fetal rat intestinal absorption of horseradish peroxidase from swallowed amniotic fluid. J. Cell. Biol., 56: 106 (1973).

18. Orlic, D., Lev, R., and Rosenthal, W. S.: Fetal rat utilization of ${ }^{55} \mathrm{Fe}$ absorbed by fetal intestine from swallowed amniotic fluid. Blood, 43: 429 (1974).

19. Pantuck, E., Conney, A. H., and Kuntzman, R.: Effect of phenobarbital on the metabolism of pentobarbital and meperidine in fetal rabbits and rats. Biochem. Pharmacol., 17: 144! (1968).

20. Rosenzweig, N. S.: Adult lactase deficiency: Genetic control or adaptive response? Gastroenterology, 60: 464 (1971).

21. Williams, R. J., and Beck, F.: A histochemical study of gut maturation. J. Anat., I05: 487 (1969).

22. Eastman Organic Chemicals, Rochester, N. Y.

23. Worthington Biochemical Corp., Freehold, N J.

24. The authors are grateful to Dr. Sara Schiller for her suggestions concerning the lactase assays. This work was supported by Grant no. 1-355 from the National Foundation-March of Dimes.

25. Requests for reprints should be addressed to: R. Lev, M.D. Department of Pathology, New York Medical College, Basic Sciences Building, Valhalla, N. Y. 10595 (USA).

26. Accepted for publication September 29, 1975.
Amino acids

brain development

glucose metabolism lipids

malnutrition

\title{
Brain Glucose Utilization in Undernourished Rats
}

\author{
H. PETER CHASE, (40) DENIS O. RODGERSON, WARREN LINDSLEY, JR., \\ THEODORE THORNE, AND GEOFFREY CHEUNG \\ University of Colorado Medical Center, Department of Pediatrics, B. F. Stolinsky Laboratories, \\ Denver, Colorado, USA
}

\section{Extract}

The in vivo incorporation of radioactivity from $\left[U-{ }^{14} \mathrm{C}\right]$ glucose was reduced in undernourished rat pups at ages 6,10 , and 17 days for brain lipids, and at age $\mathbf{1 0}$ days for brain amino acids. Brain glucose concentrations were lower at age 20 days (controls $1.58 \pm$ 0.26 vs. test $1.14 \pm 0.07 \mu \mathrm{mol} / \mathrm{g}$ ) but other alterations in brain glucose, glycogen, ATP, or phosphocreatine concentrations were not found.

Brain mitochondrial glutamate dehydrogenase activity was $\mathbf{2 1 \%}$ and $30 \%$ lower in undernourished animals at ages 10 and 20 days, respectively. Brain mitochondrial and supernatant isocitrate dehydrogenase activities and pyruvate kinase activity were similar for undernourished and control animals.

Brain glycogen levels were 2-4 times higher in late fetal and newborn control animals ( 13.6 and $15.3 \mu \mathrm{mol} / \mathrm{g}$ ) than in older animals (4.2-5.7 $\mu \mathrm{mol} / \mathrm{g})$. Brain glucose, ATP, and phosphocreatine levels increased from the 15-day fetus to the newborn, but thereafter showed no further increase.

\section{Speculation}

Reduced utilization of glucose to form lipids could account for the previously described reductions in brain lipids resulting from undernutrition.

The effects of postnatal undernutrition on brain biochemical development and on intellectual development have been summarized in several recent reviews $(5,10,12,31)$. Studies in experimental animals and in humans have shown alterations in brain weight, cell number, and in myelin lipids as a result of undernutrition. The mechanism of these alterations is as yet unknown, but could involve reduced brain glucose utilization. Glucose is the primary substrate utilized by the human or experimental animal infant brain as a source of energy, and is an important substrate in the formation of many brain intermediates. Low blood glucose levels have also been shown to be commonon in children dying of malnutrition (30). The present paper reports studies in undernourished and control rat pups of brain and liver utilization of 
$\left[U-{ }^{14} \mathrm{C}\right]$ glucose in the formation of lipids and amino acids; of brain glucose, glycogen, ATP, and phosphocreatine levels; and of the activities of four enzymes important in glucose metabolism.

\section{MATERIALS AND METHODS}

\section{ANIMALS}

Sprague-Dawley rats (32) were placed, within $12 \mathrm{hr}$ after birth into nursing litters of either 4 animals to 1 mother for good nutrition or 16 animals to 1 mother for poor nutrition. Poorly nourished animals used for adult experiments were raised in the large nursing litters until age 21 days, and were then fed a low protein $(8 \%)$ diet (33) until time of death at age 90 days. Animals were killed at appropriate ages by decapitation, except for those experiments described below in which glucose, glycogen, ATP, and phosphocreatine were determined. The pups were not fasted before time of death for any experiments.

\section{[U-14C]GLUCOSE INCORPORATION INTO LIPIDS AND AMINO ACIDS}

At ages $6,10,17$, and 24 days, animals were injected intraperitoneally with $2.5 \mu \mathrm{Ci}\left[U^{-14} \mathrm{C}\right]$ glucose $(3.0 \mu \mathrm{Ci} / \mathrm{mM})(34)$ and $0.2 \mathrm{mg}$ carrier glucose $/ 60 \mathrm{~g}$ body weight, and killed $1 \mathrm{hr}$ after injection. The brains and livers were each divided into two parts: one part to measure the in vivo rate of lipid formation and the remaining part to measure the in vivo rate of amino acid formation. The portion of brain or liver used for measurement of lipid formation was extracted in 2:1 chloroform-methanol (35) by the method of Folch et al. (14), with further analysis as described previously (6). Total brain lipid was determined gravimetrically. The amino acids were separated from other constituents by the method of Gaitonde and Richter (15) as previously described by a report from our laboratory (8).

In order to determine the total quantity of radioactivity reaching the brain, three control and three test 10-day-old rats were studied at 10,30 , and $60 \mathrm{~min}$ after the $\left[U-{ }^{14} \mathrm{C}\right]$ glucose injections. Animals were killed using liquid nitrogen and duplicate perchloric acidprecipitated samples from each brain prepared, as described below under ATP. Samples were then homogenized by hand using a ground glass homogenizer, and an aliquot was transferred to a scintillation vial with $0.4 \mathrm{~g} \mathrm{Cab-O-Sil} \mathrm{and} 10 \mathrm{ml}$ dioxane scintillation fluid. A ${ }^{14} \mathrm{C}$ standard similarly counted gave a counting efficiency of $94 \%$.

\section{ATP, PHOSPHOCREATINE, GLYCOGEN, AND GL.UCOSE}

Animals were killed by dropping into liquid nitrogen, and the brains removed and pulverized in the frozen state $\left(-80^{\circ}\right)$ as described by Lowry et al. (19). Duplicate samples of approximately $100 \mathrm{mg}$ brain powder were weighed and prepared for analysis as described previously by a report from this laboratory
(6). Glycogen and glucose (19), ATP (16), and phosphocreatine (17) were then determined as described previously (7).

\section{ENZYME DETERMINATIONS}

After decapitation the brains and livers were removed immediately, blotted free of excess blood, weighed, and placed over ice. Samples were homogenized in $10 \mathrm{ml} / \mathrm{g}$ tissue of cold homogenizing medium containing $0.05 \mathrm{M}$ Tris- $\mathrm{HCl}$ buffer, $\mathrm{pH} 7.4$, with $1 \mathrm{mM}$ dithiothreitol, $1 \mathrm{mM}$ EDTA, and $0.25 \mathrm{M}$ sucrose. Mitochondria were prepared by the method of Schneider and Hogeboom (24). NADP-linked isocitric dehydrogenase (EC. 1.1.1.42) activities of supernatant and mitochondria were determined by the method of Baker and Newburgh (2). Mitochondrial glutamic dehydrogenase (EC. 1.4.1.2) activity was determined by the method of Fahien $e t$ al. (13). Supernatant pyruvate kinase activity (EC. 2.7.1.40) was determined by the method of Tanaka et al. (28). All enzyme assays were carried out in a Gilford 2000 (36) recording spectrophotometer with automatic blank compensator and at a regulated temperature of $37^{\circ}$. All assays were performed in triplicate using at least two enzyme levels and only enzyme concentration-dependent rates were accepted. Blank cuvettes contained no substrate.

\section{RESULTS}

\section{BRAIN AND BODY WEIGHTS}

Animals raised in large nursing litters for poor nutrition had significantly lower brain and body weights at all ages than did animals raised in the small nursing litters for good nutrition (Table 1). The body weights of the poorly nourished animals at age 24 days, although statistically lower than for control animals $(P<$ 0.02 ), were higher than those usually found (4). This is attributed to an occasional mother doing exceptionally well with the large nursing litter, and to some animals rehabilitating themselves more rapidly as they began to eat the mothers' food at about age 18 days.

\section{IN VIVO GLUCOSE INCORPORATION}

$\left[U^{14} \mathrm{C}\right]$ Glucose incorporation into brain lipids (Fig. 1) was greatly decreased per $g$ wet weight of brain or per total brain in the malnourished animals. Brain lipid formation was already significantly lower in the 6-day-old animals and was only $25 \%$ of the value for well nourished control animals at age 10 days. At age 17 days, the peak time of brain lipid synthesis, the malnourished brains had less than half the rate of lipid synthesis from glucose of well nourished animals. No differences were found between lipid formation in 90 -day-old controls $(580 \pm 104 \mathrm{cpm} / 100 \mathrm{mg}$ brain $)$ and 90 -day-old malnourished animals $(495 \pm 112 \mathrm{cpm} / 100 \mathrm{mg}$ brain).

$\left[U-{ }^{14} \mathrm{C}\right]$ Glucose incorporation into brain lipids was also expressed per mg dry lipid weight. Results, expressed in counts per

Table 1. Brain and body weights ${ }^{1}$

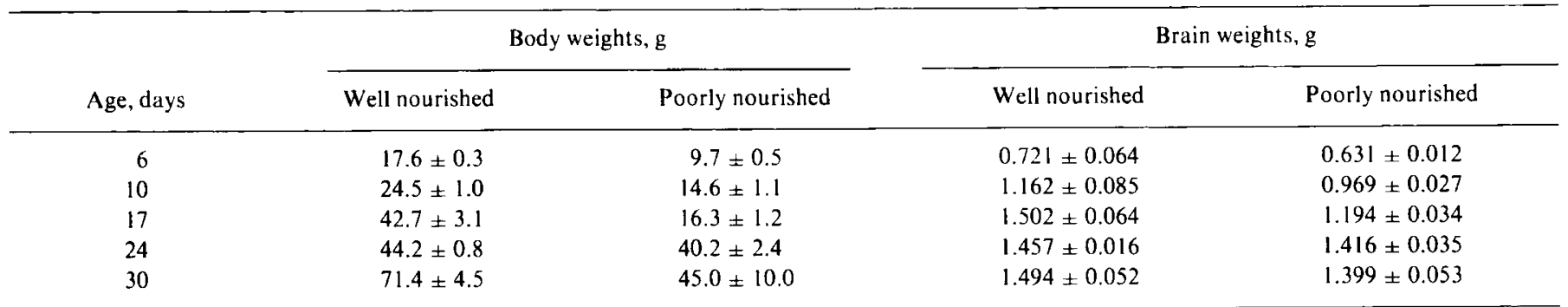

\footnotetext{
${ }^{1}$ Differences in body and brain weights are statistically different at $P<0.01$ for well nourished versus poorly nourished animals at all ages except 24 days, where $P<0.02$ for body and brain weights. Results represent the mean \pm 1 SD for the same four controls and test animals at each age as shown in the figures. All standard deviations and $t$-tests were performed by standard methods of statistical analysis (25).
} 
min per $\mathrm{mg}$ of lipid, were statistically lower $(P<0.01)$ for poorly nourished compared with well nourished animals at ages 6 days $(45.7 \pm 8.7$ vs. $61.8 \pm 2.2), 10$ days $(17.9 \pm 5.1$ vs. $78.4 \pm 13.4)$, and 17 days $(33.4 \pm 3.6$ vs. $62.1 \pm 10.1)$. The 24 -day-old previously undernourished animals had higher $(P<0.01)$ values $(73.6 \pm 12.6$ $\mathrm{cpm} / \mathrm{mg}$ lipid) than the well nourished animals $(39.8 \pm 6.3$ $\mathrm{cpm} / \mathrm{mg}$ lipid).

Brain amino acid synthesis from $\left[U-{ }^{14} \mathrm{C}\right]$ glucose was not lower in the 6-day-old poorly nourished animals, but was less than half the value for the control animals at age 10 days (Fig. 2). Significant differences between control and test animals, however, were not present at age 17 days or at age 90 days $(P<0.005)$. In contrast to brain lipid formation, brain amino acid formation did not reach a peak in early life and continued to increase in older animals. Significant differences in amino acid formation were not found between 90 -day-old well nourished $(5,365 \pm 640 \mathrm{cpm} / 100$ $\mathrm{mg}$ brain) and poorly nourished $(5,370 \pm 1.885 \mathrm{cpm} / 100 \mathrm{mg}$ brain) animals.

The patterns of $\left[U-{ }^{14} \mathrm{C}\right]$ glucose incorporation into liver were similar for both lipids and amino acids (Figs. 3 and 4). Small but

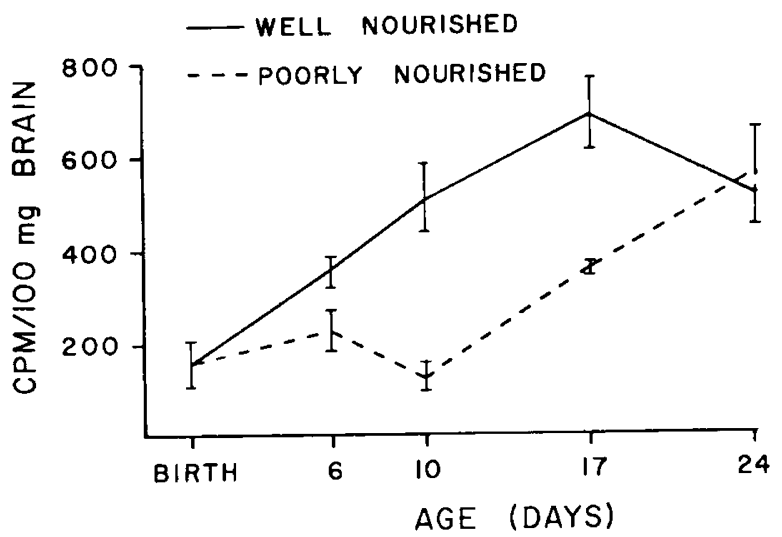

Fig. 1. $\left[U-{ }^{14} \mathrm{C}\right] \mathrm{Glucose}$ incorporation into brain lipids by well nourished $(-)$ and poorly nourished $(--)$ infant rats. Each point in this figure and in Figure 2 represents the mean of values from four animals and the vertical lines represent one standard deviation. Results were statistically different $(P<0.001)$ at ages, 6, 10, and 17 days.

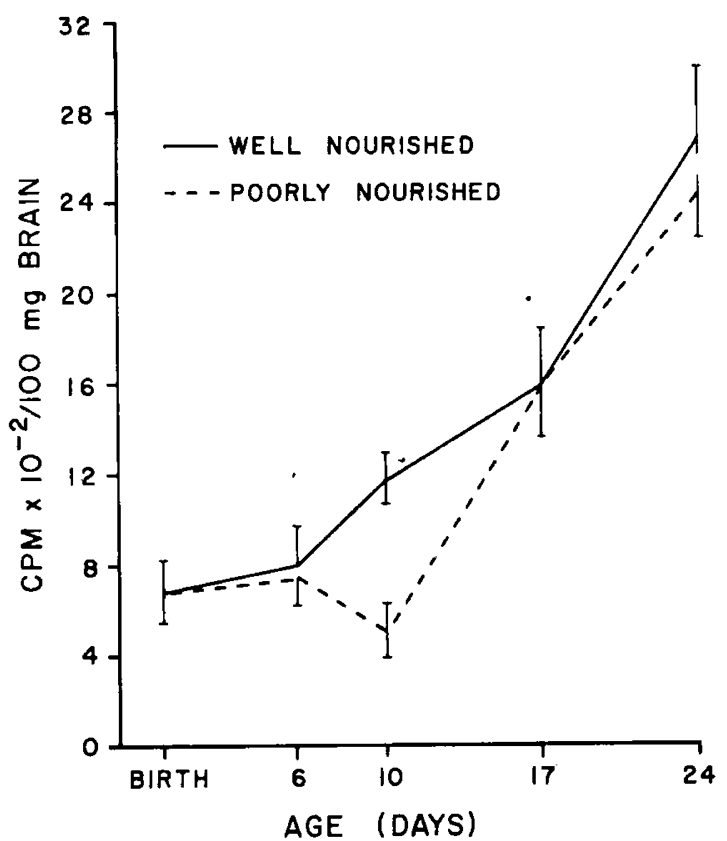

Fig. 2. $\left[U-{ }^{14} \mathrm{C}\right]$ Glucose incorporation into brain amino acids by the same well nourished $(-)$ and poorly nourished $(---)$ infant rats as in Figure 1. Results were statistically different $(P<0.001)$ only at age 10 days.

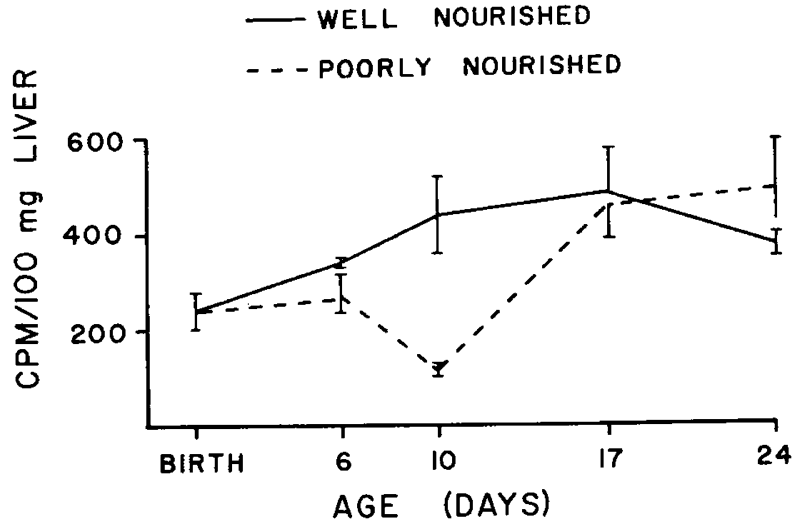

Fig. 3. $\left[U-{ }^{14} \mathrm{C}\right]$ Glucose incorporation into liver lipids by the same well nourished (-) and poorly nourished (- -$)$ infant rats as in Figure 1. Results were statistically different $(P<0.001)$ at ages 6 and 10 days.

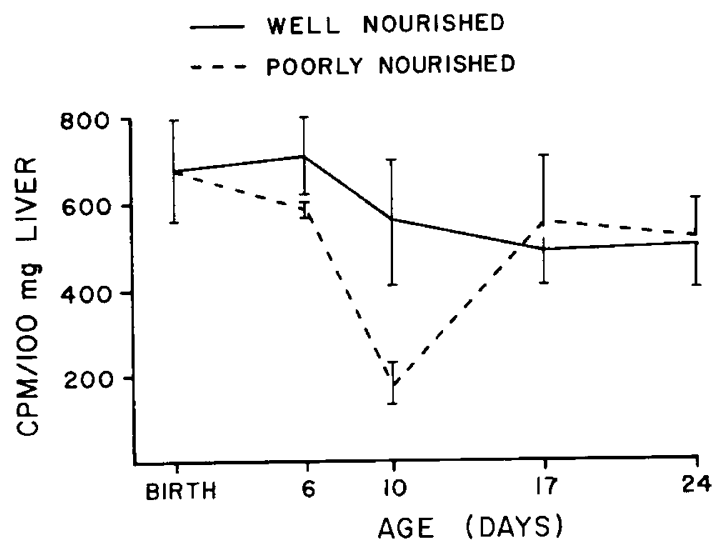

Fig. 4. $\left[U-{ }^{14} \mathrm{C}\right] \mathrm{Glucose}$ incorporation into liver amino acids by the same well nourished $(-)$ and poorly nourished $(--)$ infant rats as in Figure 1. Results were statistically different $(P<0.01)$ at ages 6 and 10 days.

statistically significant differences were present between control and test animals for both hepatic lipid and amino acid formation at age 6 days, and three- to four-fold differences were present at age 10 days. Lipid and amino acid formation were similar per $g$ wet weight of liver in the 17- and 24-day-old control and test animals.

The total quantity of radioactivity, expressed in counts per min per $0.1 \mathrm{~g}$ brain, was similar $(P>0.05)$ for control and test animals, respectively, at $10 \mathrm{~min}: 4,882$ vs. $6,230,30 \mathrm{~min}$ : $11,048 \mathrm{vs}$. 11,357 , and $60 \mathrm{~min}: 11,929$ vs. 13,947 .

\section{CONCENTRATIONS OF ATP, PHOSPHOCREATINE, GLYCOGEN, AND GLUCOSE}

The concentrations of ATP and phosphocreatine were not significantly different in the brains of malnourished animals as compared to controls at ages 10 or 20 days (Table 2). The brain concentrations of both ATP and phosphocreatine were found to increase markedly from the 15-day-old fetus to the newborn animal (Table 2).

Glucose levels were statistically lower $(P<0.05)$ in the malnourished brains at age 20 days (Table 2 ), but levels of other intermediates did not vary between control and test animals $(P>$ 0.05 ). Blood glucose concentrations were lower in malnourished animals $(91 \pm 12 \mathrm{mg} / 100 \mathrm{ml})$ than in well nourished animals (129 $\pm 4 \mathrm{mg} / 100 \mathrm{ml}$ ) at age 10 days, but were similar at age 20 days when the pups had already initiated rehabilitation by eating the mothers' diet. Brain glucose concentrations increased from 1.54 $\mu \mathrm{mol} / \mathrm{g}$ in the 15 -day-old fetus to $2.39 \mu \mathrm{mol} / \mathrm{g}$ in the newborn, and then fell slightly in older animals. Glycogen concentrations fell 
markedly in the brain after birth with $13-15 \mu \mathrm{mol} / \mathrm{g}$ brain in the fetal and newborn animals, and levels of only $4.28 \mu \mathrm{mol} / \mathrm{g}$ in 10-day-old animals. Levels of brain glycogen remained relatively constant after age 10 days.

\section{ENZYME ACTIVITIES}

Mitochondrial glutamate dehydrogenase activity in brains from malnourished animals was statistically lower $(P<0.01)$ at age 20 days (Table 3). Activity also was lower at age 10 days, but the difference was not statistically significant $(P>0.05)$. Activities in the livers of the malnourished rats were $81 \%$ lower at age 10 days $(P<0.01)$ and $49 \%$ lower at age 20 days $(P>0.05)$.

Supernatant and mitochondrial NADP-isocitric dehydrogenasespecific activities were not decreased $(P>0.05)$ in the brains of malnourished animals at ages 10 or 20 days (Table 3 ). Activities in the liver mitochondria were statistically lower $(P<0.01)$ in malnourished animals at age 10 days (Table 3 ), but other results did not vary statistically $(P>0.05)$ between control and test animals.

Table 2. Brain high energy intermediates ${ }^{2}$

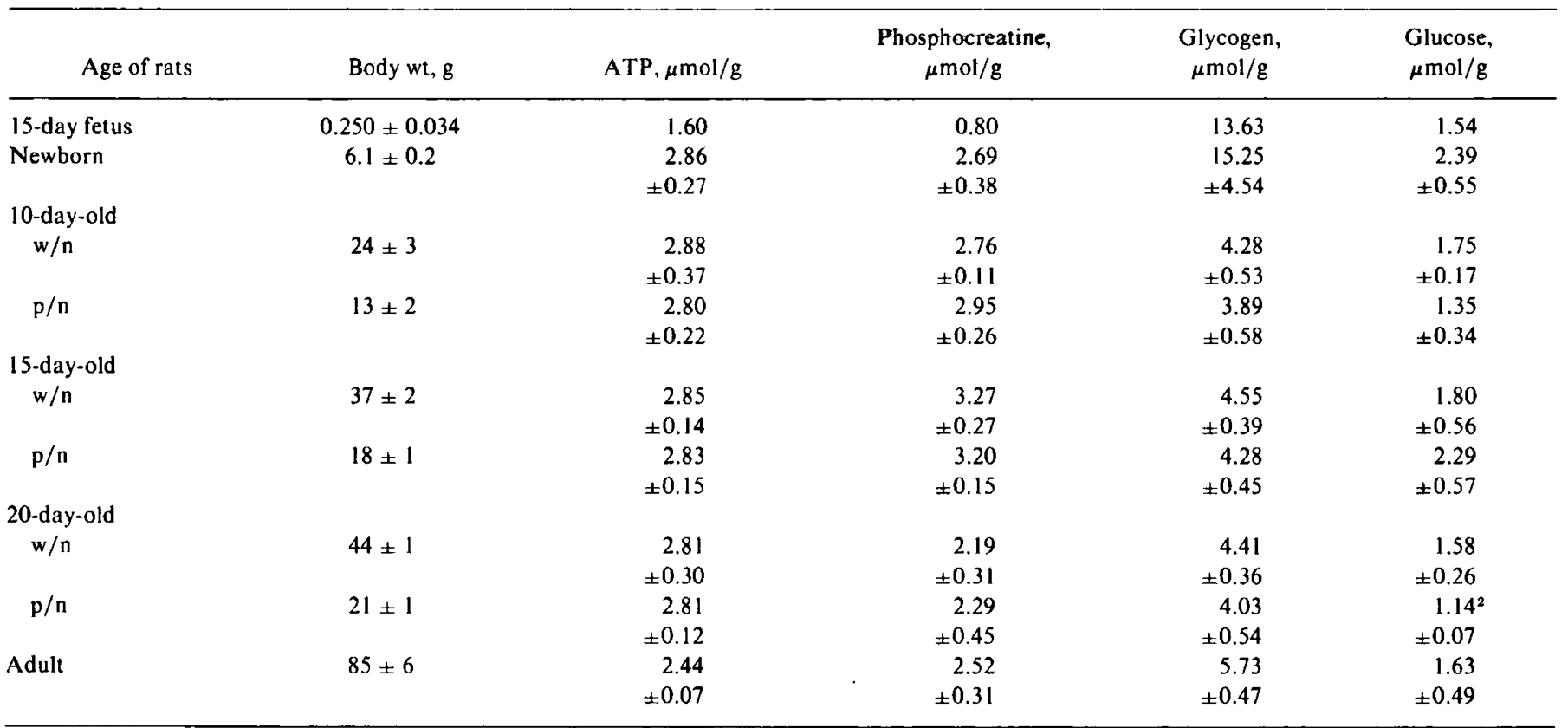

${ }^{1}$ Each value represents the mean of duplicate determinations from four different animals \pm 1 SD. $w / n$ : well nourished; $p / n$ : poorly nourished.

${ }^{2} P<0.05$.

Table 3. Enzyme specific activities ${ }^{1}$ in brains and livers of well nourished and poorly nourished rats

\begin{tabular}{|c|c|c|c|c|}
\hline & $\begin{array}{l}\text { Mitochondrial } \\
\text { glutamate } \\
\text { dehydrogenase }\end{array}$ & $\begin{array}{l}\text { Mitochondrial } \\
\text { isocitrate } \\
\text { dehydrogenase }\end{array}$ & $\begin{array}{l}\text { Supernatant } \\
\text { isocitrate } \\
\text { dehydrogenase }\end{array}$ & Pyruvate kinase \\
\hline \multicolumn{5}{|l|}{10 days old } \\
\hline \multicolumn{5}{|l|}{ Brain } \\
\hline Controls & $38.5 \pm 5.4$ & $42.2 \pm 6.7$ & $40.1 \pm 4.9$ & $820.0 \pm 160.0$ \\
\hline Malnourished & $30.4 \pm 5.5$ & $45.0 \pm 8.4$ & $43.5 \pm 10.2$ & $730.0 \pm 50.0$ \\
\hline Controls & $206.8 \pm 18.4$ & $138.4 \pm 20.3$ & $172.2 \pm 32.3$ & $210.0 \pm 30.0$ \\
\hline Malnourished & $39.5 \pm 9.1^{2}$ & $70.5 \pm 19.8^{2}$ & $142.9 \pm 9.2$ & $150.0 \pm 90.0$ \\
\hline$\%$ Change decrease & 81 & 49 & 17 & 29 \\
\hline \multicolumn{5}{|l|}{20 days old } \\
\hline \multicolumn{5}{|l|}{ Brain } \\
\hline Controls & $58.9 \pm 6.7$ & $23.1 \pm 0.2$ & $18.7 \pm 2.6$ & $1230.0 \pm 170.0$ \\
\hline$\%$ Change decrease & 49 & 40 & & 67 \\
\hline
\end{tabular}

${ }^{1}$ Specific activities are defined as millimicromoles of product formed per miniper $\mathrm{mg}$ of protein. Each value represents the mean $\pm \mathrm{I}$ SD of determinations done (in triplicate, with the mean of three values used) on tissues of four animals, except pyruvate kinase, where eight animals were studied.

${ }^{2} P<0.01$.

${ }^{3} P<0.05$. 
Although pyruvate kinase activities were slightly lower in the brains (11\%) and livers (29\%) of 10-day-old malnourished animals (Table 3$)$, the differences were not statistically significant $(P>$ 0.05 ). At age 20 days there was no difference in brain pyruvate kinase activity, although hepatic activity was lower $(P<0.01)$ in malnourished animals. Pyruvate kinase activities in muscle were not significäntly different $(P>0.05)$ either at age 10 days $(1.22 \pm$ 0.23 vs. $1.36 \pm 0.26$ for cont rols $)$ or 20 days $(2.97 \pm 1.75$ vs. $5.22 \pm$ 0.82 for controls).

\section{DISCUSSION}

Glucose is the primary substrate used by the infant brain for energy metabolism and also serves as a substrate in the formation of many biochemical intermediates. The reduced incorporation of radioactivity from $\left[U_{-14}^{14}\right]$ glucose to lipids in the brains of the malnourished rat pups could be the cause of lowered formation of myelin or cell wall lipids, or could just be secondary to the diminished quantities of these structures with a resultant lesser need for lipid. It was considered possible that reduced availability of glucose to the brain might occur, either because of brain uptake or low blood glucose levels. Hypoglycemia is a frequent finding in children dying of malnutrition (30). However, blood and brain glucose levels were not in the range associated previously with hypoglycemia and impaired myelin lipid development in infant rats (7). Furthermore, the total radioactivity reaching the brain was similar in control and test animals. This does not absolutely rule out alterations in brain glucose uptake, however, particularly at a subcellular level. It should also be noted that the rate of formation of amino acids was unaltered at ages 6 and 17 days when lipid synthesis was lower. If reduced glucose was reaching the brain it might have been expected that the formation of both would have been lower. Another possibility, which can not be ruled out from the present experiments, is that the amino acid and energy needs of the brain have priority in glucose utilization, with less substrate available in compromised situations for lipid synthesizing pathways. Protein malnutrition may also be important in explaining the reduced incorporation of radioactivity into lipids. The pups from the large nursing litters are believed to be deficient in calories and protein, and if inadequate essential amino acids are available, altered ribosome function as described by Munro (20) in liver and/or reduced enzyme formation and/or activity $(4,6)$ could be responsible for reduced lipid formation.

Total radioactivity incorporated into brain lipid was expressed per $\mathrm{mg}$ dry lipid weight as well as per $100 \mathrm{mg}$ wet brain weight. Incorporation per $\mathrm{mg}$ lipid might have been anticipated to have been similar in well nourished and poorly nourished brain had changes in brain lipid synthesis been the only alteration in the poorly nourished animals. Results were not similar, with the reduction in radioactivity per $\mathrm{mg}$ lipid weight $(26-77 \%$ at ages 6-24 days) similar to the reduction per $100 \mathrm{mg}$ wet brain weight (Fig. 1), and consistently greater than the quantitative reduction in dry lipid weight $(11-25 \%$ at the various ages) in the poorly nourished animals. These findings may be related to other alterations in the availability or metabolism of glucose, or to changes in utilization of other substrates to supply acetate for the synthesis of cholesterol and other lipids. Patel and Tonk onow (22) compared the in vitro utilization of $\left[U-{ }^{14} \mathrm{C}\right]$ acetate and $[U-$ ${ }^{14} \mathrm{C}$ ]glucose in rat brain slices, finding both substrates readily incorporated into nonsaponifiable lipids and fatty acids. Rates of incorporation and the ages of maximal incorporation varied for the two substrates, and would be of interest to further evaluate in vivo in control and poorly nourished rats.

Evidence was not found to suggest reduced availability of "high energy intermediates," which could occur as a result of impaired glucose utilization. Glycolysis serves as a source of brain energy in the formation of ATP, which is necessary for the continual repolarization of nerve cells, as well as for other metabolic functions. The storage of these compounds is so low in brain that continued glycolysis is essential in maintaining ATP levels (21).
Levels of ATP, phosphocreatine, glycogen, and glucose have also been found to be similar in 11-day-old malnourished and control rats (29). Lowry et al. (19) found similar levels of ATP and phosphocreatine in 10-day-old mouse brain as we found in 15-day-old rat brain. The lower levels of phosphocreatine than of ATP in the 15-day-old fetal animals may represent hypoxia related to the mothers' ether anesthesia, as levels are usually similar or higher for phosphocreatine (21) compared with ATP (19). Although the brain glucose levels in this investigation are similar to those described by Lowry et al. (19) in mouse brain, glycogen levels are somewhat higher. This is most likely related to species differences.

Also in support of adequate energy resources, the activity of the soluble fraction of NADP-isocitric dehydrogenase, which is believed to form NADPH for lipid synthesis, was not reduced in the brains of the undernourished animals (Table 3). In a previous study, Swaiman et al. (26) found no reduction in the specific activities of brain isocitric dehydrogenase or of 1,6-diphosphofructose aldolase (per mg DNA) in undernourished adult rats. Pyruvate kinase activity, believed to be one of the rate limiting steps in brain glycolysis (27), was similar in control and test brains and would favor brain glycolysis not being reduced. The reduced liver pyruvate kinase activity might, in contrast, suggest lowered hepatic glycolysis. It is possible that some glycolytic product, such as acetate, might be less available to the brain tissue for lipid synthesis as a result of reduced hepatic formation.

Glutamic dehydrogenase activity was reduced $21 \%$ and $30 \%$ in the brains, and $49 \%$ and $81 \%$ in the livers of the 10 - and 20 -day-old undernourished animals. Rajalakshmi et al. (23) have also described reduced glutamic dehydrogenase activity in the brains of undernourished infant rats. This enzyme catalyzes the initial step in removal of $\alpha$-ketoglutarate from the Krebs cycle to form glutamate, which can then enter the important $\gamma$-aminobutyric acid (GABA) cycle in the brain. It has previously been shown that the main amino acids formed in the brain after $\left[U-{ }^{14} \mathrm{C}\right] \mathrm{glucose}$ injection are glutamate (approximately $50 \%$ ), aspartate (approximately $10 \%$ and also formed from glutamate), and GABA (approximately 10\%) (18). Reductions in activity of glutamic dehydrogenase might explain the reduced incorporation of radioactivity from $\left[U-{ }^{14} \mathrm{C}\right]$ glucose into brain amino acids at age 10 days. Brains from control 20-day-old rats had over $50 \%$ higher specific activity than at 10 days (Table 3 ). Thus the $21 \%$ reduction in activity in undernourished animals at age 10 days may be more important physiologically than the $30 \%$ reduction at age 20 days. The rise in specific activity of this enzyme, and possibly of other enzymes of the GABA cycle, are likely related to the increased rate of amino acid synthesis from $\left[U-{ }^{14} \mathrm{C}\right]$ glucose with increasing age (Fig. 2). Balazs and Patel (3) also found a reduction in the age-dependent increase in the conversion of glucose carbon into amino acids in undernourished rats, with a normal ratio of glutamine to glutamate specific activity. At ages 10 to 17 days, in the present study, the $\left[U-{ }^{14} \mathrm{C}\right] \mathrm{glucose}$ incorporated into brain lipids was much greater $(6,0008,000 \mathrm{cpm} / \mathrm{g}$ wet weight) than that incorporated into brain amino acids $(1,200-1,600 \mathrm{cpm} / \mathrm{g}$ wet weight). As noted previously by Gaitonde and Richter (15), older animals incorporate a larger percentage of radioactivity from glucose into amino acids than do young animals. In older animals brain amino acid synthesis utilizes a larger percentage of the $\left[U-{ }^{14} \mathrm{C}\right]$ glucose than does lipid synthesis (Fig. 2). Undernutrition in infant rats might thus be expected to have a greater effect on lipid synthesis than on amino acid synthesis, as was found to be true, whereas in older rats undernutrition might be expected to have a greater impact on amino acid synthesis than on lipid synthesis.

Results from a previous study (18) in which similar quantities of $\left[U-{ }^{14} \mathrm{C}\right] \mathrm{glucose}$ were injected into adult control animals and adult protein-starved animals of a much lower body weight showed increased incorporation of $\left[U_{-14}{ }^{14} \mathrm{C}\right] \mathrm{glucose}$ into brain amino acids of the poorly nourished animals. The increased incorporation in the undernourished animals was likely due to the greatly reduced body weights, with no reduction in brain weights, so that 
considerably more $\left[U-{ }^{14} \mathrm{C}\right]$ glucose per $\mathrm{g}$ brain weight was given to the protein-starved animals. Differences in the incorporation of radioactivity into amino acids or lipids were not found between protein-deprived and well fed adult control animals in the present study when glucose was administered on the basis of body weight. Agrawal et al. (1) studied 28-day-old undernourished and control rats, and found a $25 \%$ reduction of $\left[U-{ }^{14} \mathrm{C}\right]$ glucose into brain protein, a $21 \%$ reduction into phospholipid, a $35 \%$ reduction into glycolipid, and a $14 \%$ reduction into cholesterol in the brains of the undernourished compared with the control animals. The litter sizes were larger ( 22 pups/mother) than in the present study, and the undernutrition greater. The 24-day-old animals in the present study were rapidly rehabilitating themselves by eating the maternal diet, and no longer had a reduction in the incorporation of $\left[U-{ }^{14} \mathrm{C}\right]$ glucose into brain lipids.

The fetal and newborn brain glycogen levels were found to be 3-4 times higher than in older animals. These results are somewhat different than in a previous report (9) and may be due to the recently developed methods of quick freezing to prevent glucose and glycogen breakdown. The present method of glycogen determination relies on determination of total hydrolyzed glucose and it is likely that small fractions of the glucose are contributed from sources other than glycogen. The high fetal brain glycogen results in a store of brain glycogen as the maternal glucose supply is cut at birth and correlates with the previously described increased concentrations of fetal liver glycogen in all species which have been studied (11).

\section{SUMMARY}

Reduced radioactivity from $\left[U-{ }^{14} \mathrm{C}\right]$ glucose was incorporated in vivo into brain lipids of undernourished rat pups at ages 6,10 , and 17 days, and into brain amino acids at age 10 days. Alterations in brain ATP, phosphocreatine, glycogen, and glucose (except at age 20 days) were not found.

\section{REFERENCES AND NOTES}

1. Agrawal, H. C., Fishman, M. A., and Prensky, A. L.: A possible biock in the intermediary metabolism of glucose into proteins and lipids in the brains of undernourished rats. Lipids, 6: 431 (1971).

2. Baker, W. W., and Newburgh, R. W.: Intracellular distribution of isocitratenicatinamide-adenine dinucleotide phosphate-oxidoreductase activity during and brain development. Biochem. J. 89: 510 (1963).

3. Balazs, R., and Patel, A. J.: In: D. H. Ford: Progress in Brain Research, Vol. 40, p. 115 (Elsevier, Amsterdam, 1973).

4. Brasel, J., John, B. S., and Ehrenkranz, R. A.: Patterns of DNA polymerase activity in normal rat forebrain and cerebellum in the suckling period. Growth, 37: 301 (1973)

5. Chase, H. P.: The effects of intrauterine and postnatal undernutrition on normal brain development. Ann. N. Y. Acad. Sci.. 205: 231 (1973).

6. Chase, H. P., Dorsey, J., and McKhann, G. M.: Effect of malnutrition on synthesis of myelin lipids. Pediatrics, 40: 551 (1967).

7. Chase, H. P., Marlow, R. A., Dabiere, C. S., and Welch, N. N.: Hypoglycemia and brain development. Pediatrics, 52: 513(1973).

8. Chase, H. P., Schmickrath, R. C., Welch, N. N., and Dabiere, C. S.: Influence of thyroid hormone on brain glucose conversion to amino acids. Brain Res., 75: 295 (1974).

9. Chesler, A., and Himwich, H. E.: Glycogen content of various parts of the central nervous system of dogs and cats at different ages. Arch. Biochem.. 2: 175 (1943).

10. Coursin, D. B., Barnes. R. H., Birch, H. G., Klein, R., and Winick, M.: The relationship of nutrition to brain development and behavior. A position paper of the Food and Nutrition Board, National Academy of Sciences. National Research Council, Washington, D.C.. June, 1973.

11. Dawkins, J. R.: Biochemical aspects of developing function in newborn mammalian liver. Brit. Med. Bull., 22: 27 (1966).

12. Dobbing, J., and Smart, J. L.: Early undernutrition, brain development and behavior. In: S. A. Barnett: Ethology and Development, p. 16 (Spastics International Medical Publications, Ltd., London, 1973).

13. Fahien, F. A., Wiggert, B. O., and Cohen, P. P. Crystallization and kinetic properties of glutamate dehydrogenase from frog liver. J. Biol. Chem., 240: 1083 (1965).

14. Folch, J., Lees, M., and Sloan-Stanley, G.: A simple method for the isolation and purification of total lipids from animal tissues. J. Biol. Chem. 226:497 (1957)

15. Gaitonde, M. K., and Richter, D.: Changes with age in the utilization of glucose carbon in liver and brain. J. Neurochem., 13: 1309 (1966).

16. Greengard, P.: Adenosine-5-triphosphate: Determination by fluorimetry. In: H. V. Bergmeyer: Methods Enzymatic Analysis, p. 551 (Academic Press, New York, 1965).

17. Lamprecht, W., and Stein. P.: Creatine phosphate. In: H. V. Bergmeyer: Methods of Enzymatic Analysis, p. 610 (Academic Press. New York, 1965).

18. Lehr, P., and Gayet, J.: Response of the cerebral cortex of the rat to proionged protein depletion. III. Entry of glucose carbon into free amino acids in vivo. J. Neurochem. 14:927 (1967).

19. Lowry, O. H., Passonneau, J. V., Hasselberger, F. X., and Schulz, D. W.: Effec of ischemia on known substrates and cofactors of the glycolytic pathway in brain. J. Biol. Chem., 239: 18 (1964).

20. Munro, H. N.: Role of amino acid supply in regulating ribosome function. Fed Proc.. 27: 1231 (1968).

21. O'Neill, J. J., Simon, J. H., and Shreeve, W. W.: Alternate glycolytic pathways in brain. A comparison between the action of artificial electron acceptors and electrical stimulation. J. Neurochem., 12: 797 (1965).

22. Patel, M. S., and Tonkonow, B. L.: Development of lipogenesis in rat brain cortex: The differential incorporation of glucose and acetate into brain lipids in vitro. J. Neurochem., 23: 309 (1974).

23. Rajalakshmi, R., Parameswaran, M., Telang, S. D., and Ramakrishnan, C. V.: Effects of undernutrition and protein deficiency on glutamate dehydrogenase and decarboxylase in rat brain. J. Neurochem., 23: 129 (1974).

24. Schneider, W. C., and Hogeboom, G. H.: Intracellular distribution of enzymes V. Further studies on the distribution of cytochrome $c$ in rat liver homogenate J. Biol. Chem., 183: 123 (1950).

25. Snedecor, G. W.: Statistical Methods Applied to Experiments in Agriculture and Biology, Ed. 5, p. 45. (Iowa State College Press. Ames, lowa, 1956).

26. Swaiman, K. F., Daleiden, J. M., and Wolfe, R. N.: Effect of food deprivation on enzyme activity in developing brain. J. Neurochem., 17: 1387 (1970).

27. Takagaki, G.: Control of aerobic glycolysis and pyruvate kinase activity in cerebral cortex slices. J. Neurochem., 15: 903 (1968).

28. Tanaka, K. R., Valentine, W. N., and Miwa, S.: Pyruvate kinase (PK) deficiency in hereditary non-spherocytic hemolytic anemia. Blood, 19: 267 (1962).

29. Thurston, J. H., Prensky. A. L., Warren. S. K., and Albone, K.-R.: The effects of undernutrition upon the energy reserve of the brain and upon other selected metabolic intermediates in brains and livers of infant rats. J. Neurochem., 18 . 161 (1971).

30. Wharton, B.: Hypoglycemia in children with kwashiorkor. Lancet, $i: 171$ (1970)

31. Winick, M.: Malnutrition and brain development. J. Pediat., 74: 667 (1969).

32. Simonsen Laboratories, Gilroy, Calif.

33. Nutritional Biochemicals, Cleveland, Ohio

34. Amersham Searle Corporation, Arlington Heights, lll.

35. Chloroform, methanol, and toluene were purchased from J. T. Baker Chemical Co., Phillipsburg, N. J. All solvents were redistilled prior to use. Unless otherwise noted all other reagents were purchased from Sigma Chemical Co. St. Louis, Mo.

36. Gilford 2000. Gilford Instrument Laboratories, Oberlin, Ohio

37. The authors gratefully acknowledge the skillful technical assistance of Miss N. N Welch and Mrs. C. S. Dabiere, and the help of Mrs. Delores Martin in preparing the manuscript.

38. Results of this study were presented in part to the Society for Pediatric Research in April 1971, Atlantic City. N. J.

39. This work was supported by Grant no. NS 07537-04 NEUB, Department of Health, Education and Welfare and Grant no. HS 0315-0IAT0376A11111, National Institutes of Health Retardation Studies. National Institutes of Health, Bethesda, Maryland.

40. Requests for reprints should be addressed to: H. P. Chase, M.D., University of Colorado Medical Center, 4200 East Ninth Ave., Denver, Color. 80220 (USA). 41. Accepted for publication September 29, 1975. 